\title{
Retinoblastoma TNM Finding v8
}

National Cancer Institute

\section{Source}

National Cancer Institute. Retinoblastoma TNM Finding v8. NCI Thesaurus. Code C140675.

A finding about one or more characteristics of retinoblastoma, following the rules of the TNM AJCC v8 classification system. This classification does not apply to central nervous system component of "trilateral retinoblastoma" (is staged according to the classification for brain and spinal cord), retinoma (or retinocytoma) (no AJCC staging system), and medulloepithelioma (no AJCC staging system). (from AJCC 8th Ed.) 